\title{
The European Union as a Peace Actor
}

\author{
Yannis A. Stivachtis ${ }^{1}$, Chris Price $^{2} \&$ Mike Habegger $^{3}$ \\ ${ }^{1}$ Department of Political Science, Virginia Tech, VA, USA \\ ${ }^{2}$ School of Public and International Affairs (SPIA), Virginia Tech, VA, USA \\ ${ }^{3}$ Department of Political Science, University of Delaware, DE, USA \\ Correspondence: Yannis A. Stivachtis, Department of Political Science, Virginia Tech, 119 Major Williams Hall, \\ Blacksburg, VA 24061, USA. Tel: 1-540-231-5816. E-mail: ystivach@vt.edu
}

Received: March 12, $2013 \quad$ Accepted: July 3, $2013 \quad$ Online Published: July 5, 2013
$\begin{aligned} & \text { doi:10.5539/res.v5n3p4 } \\ & \text { URL: http://dx.doi.org/10.5539/res.v5n3p4 }\end{aligned}$

\begin{abstract}
The purpose of this essay is first, to examine European Union's conceptualization of peace and security; and second, to discuss how the European Union (EU) seeks to contribute to international peace and security. It begins with a discussion of the EU's understanding of peace and security and then proceeds with the EU's identification of threats to international peace and security. The paper then focuses on the EU's security strategy to identify how the EU seeks to address challenges to international order and stability. Finally, the paper employs the concepts of 'civilian', 'military' and 'normative power Europe' to demonstrate how the EU attempts to create international security and stability both at the regional and international levels. It argues that the EU employs both 'civilian' and 'military' means in the application of its 'normative' power.
\end{abstract}

Keywords: European Security Strategy, European Neighborhood Policy, multilateralism, civilian power, military power, normative power

\section{Introduction}

During the first half of the twentieth century, Europe was wracked with military conflict, leaving an estimated one hundred million dead between the two world wars. Resolved to prevent another continental war, European governments searched for a plan. Numerous proposals were put forth, but not all were implemented - the European Defense Community, for example. On the $9^{\text {th }}$ of May of 1950, French Foreign Minister Robert Schuman proposed the creation of a European Coal and Steel Community (ECSC) in which the Member States would combine their coal and steel production. By pooling heavy industry, they aimed to make war between historic rivals France and Germany "not merely unthinkable, but materially impossible" (EU: Schuman Declaration). In 1958, the European Economic Community (EEC) was brought to life. The EEC aimed to promote peace in Western Europe through a shared market system. As both organizations sought peace through economic unification and shared many core values they eventually integrated and streamlined.

Thus from its nascent form, what is known today as the European Union (EU) constituted a 'security project' providing France and the rest of Europe security from a rearmed Germany (Kirchner \& Sperling, 2007: 1). Ian Manners (2002: 240) suggests that the EU was created in a post-war historical environment, which reviled the nationalisms that had led to barbarous war and genocide. Because of this, the creation of Community institutions and policies took place in a context where Europeans were committed to "pooling their resources to preserve and strengthen peace and liberty" [preamble to the Treaty establishing the European Communities (TEC)]. Therefore from the very beginning, members of the then EEC had already recognized that security is a multifaceted concept, embodied in both tangible and intangible fashions.

The purpose of this essay is twofold: first, it seeks to examine European Union's conceptualization of peace and security; and second, to discuss how the EU seeks to contribute to international peace and security.

\section{The European Union as a Peace Actor}

There is a general consensus that the EU represents a new kind of power in international politics (Diez, 2005; Manners, 2002; Whitman, 1998) and that it plays an ever increasing role in world affairs (Elgstrom \& Smith, 2006; Stivachtis, $2007 \&$ 2010; Orbie, 2008). Nowhere is the increasing important role of the EU - as a single international actor - in world affairs better reflected that in the European Foreign and Security Policy (EFSP). 
During the past few years, the EFSP has continued its steady development and the EU has gained additional status as an international political player (Kirchner \& Sperling, 2007). Increasingly, international crises around the world reveal the EU's added value. Sometimes the EU acts independently, sometimes as a participant in a UN-led process and sometimes in close collaboration with other international partners, like the United States, NATO or the African Union (AU). The range of instruments at the EU's disposal continues to increase in size and scope. The use of these instruments is guided by the ambitious objectives set out in the European Security Strategy (ESS) that was adopted in December of 2003 (ESS, 2003). Despite the criticism it has received and the calls for its revision (Leonard \& Gowan, 2004; Andersson et al., 2011; Lundin, 2012), for the first time, the ESS established principles and set clear objectives for advancing the EU's security interests based on the EU's core values. The ESS represents a comprehensive approach to EU's security. The "Report on the Implementation of the European Security Strategy" that was presented in December of 2008 did not seek to replace the ESS, but to reinforce it (EC 2008: 1). It provided the EU decision-makers with an opportunity to examine how the EU fared in practice, and what could be done to improve its implementation. Nevertheless, in doing so, it highlighted and emphasized security issues that had not received adequate attention in the 2003 document.

As a Union of twenty-seven states with over 500 million inhabitants ( $7.3 \%$ of the world population), generating a nominal gross domestic product (GDP) of 16.584 trillion US dollars (representing approximately $20 \%$ of the global GDP when measured in terms of purchasing power parity [PPP] and representing the largest nominal GDP and GDP-PPP in the world), and with a wide range of instruments at its disposal, the EU is inevitably a global player. Although the end of the Cold War has left the United States in a dominant position as a military actor, the Iraq and Afghan wars have demonstrated that no single state is able to tackle today's complex international problems on its own. As a result, the EU has sought to work independently as well as in collaboration with other countries and international organizations in addressing international security problems.

It is generally accepted that an active and capable EU would make an impact on a global scale. Drawing on a unique range of instruments, the EU already contributes to a more secure world by working to build human security, by reducing poverty and inequality, promoting good governance and human rights, assisting development, and addressing the root causes of conflict and insecurity. The EU also remains the biggest donor to countries in need. In addition, in the last fifteen years European forces have been deployed abroad to places as distant as Afghanistan, East Timor and the DRC.

The increasing convergence of European interests and the strengthening of mutual solidarity of the EU makes the Union a more credible and effective actor. The ESS reflects the ambition of the EU to share in the responsibility for global security and in building a more peaceful and prosperous world. However, long-term engagement is required for a lasting international peace and security to be achieved.

\section{European Union's Conceptualization of Peace and Security}

Since 1945, Europe is experiencing what is possibly its most peaceful period in recorded history. The violence exemplified by the world wars seems to be a thing of the past. On the $12^{\text {th }}$ of October of 2012, the EU was awarded the Nobel Peace Prize. Thorbjørn Jagland, Chairman of the Nobel Committee, proclaimed "that the EU has been a driving force for peace and democracy after the Second World War" and the eU transformed Europe "from a continent of war to a continent of peace" (EC, 2012a). José Manuel Barroso, President of the European Commission, and Herman Van Rompuy, President of the European Council, jointly offered a press release following acceptance of the award, asserting that "over the last sixty years, the European Union has reunified a continent split by the Cold War around values of respect for human dignity, freedom, democracy, equality, the rule of law and respect for human rights." The presidents explicitly illustrated the EU's conceptualization of peace and security as they elaborated: "these are also the values that the European Union promotes to make the world a better place for all. The European Union will continue to promote peace and security in the countries close to us and the world at large" (EC, 2012b). In other words, the EU has sought to conceptualize peace and security in terms of economic development and prosperity as well as the creation of strong democratic states.

However, in order to deal effectively with issues undermining international peace and security, the EU first needed to establish its own foreign policy framework. As Nathalie suggests, it was not until the Maastricht Treaty in 1991 that the EU specified its foreign policy objectives. With the introduction of the Treaty, these objectives included "conflict resolution, strengthening international security, promoting regional cooperation, combating international crime, and promoting democracy and the rule of law and human rights" (Tocci, 2007: 7).

Although economic prosperity and democracy helped to establish peace and security within the Union, the situation beyond the EU's borders in the early 1990s was quite different. The Yugoslav wars, beginning in 1991, 
revealed that the peace conditions existing within the EU were lacking outside its territorial framework. To address the situation, the EC's administration under then-president Jacques Delors first offered the carrot of 'special associations' to states "committed to peace and democratic reforms" (Merlingen and Ostrauskaite 2006: 35). At the time, the thought was that if this approach did not work, then economic sanctions would. If the belligerents showed no sign of cooperation, the EU would be compelled to urge the Western European Union (WEU) to employ peacekeeping troops (Merlingen \& Ostrauskaite, 2006: 35). This strategy had no significant effect. Yugoslavia descended into conflict while the EU could not reach a consensus on the use of force. As a result, the EU became an onlooker.

The EU's failure to restore order in its backyard led to the display of U.S. unilateralism. These damaging results encouraged EU policy makers to re-evaluate what had been their orthodox security policies. The further addition of Germany's flashbacks of war atrocities and the failing of the EU's perceived corporate identity forced further consideration of the EU's non-fulfillment of perceived peacekeeping duties (Merlingen and Ostrauskaite 2006: 36). Both individual member states and the European Commission saw the Yugoslav wars not as exceptions to the norm, but as a warning of times to come (Merlingen \& Ostrauskaite, 2006: 37).

Its inability to deal effectively with the Yugoslav crisis, led the EU to undertake measures and institutional changes necessary to address issues pertaining to international peace and security. For example, in the wake of the Dayton negotiations came the Petersburg Tasks, which were aimed at coping with potential destabilization in Eastern Europe. Later, the development of the Common Foreign and Security Policy (CFSP) and the European Defense and Security Policy (ESDP) became the natural outcomes of this process (Stivachtis, $2004 \& 2005$ ). Furthermore, the draft Constitutional Treaty cited the EU's external action as aiming at "preserving peace, preventing conflicts and strengthening international security" (Tocci, 2007: 7). To do so, the EU would be guided by the principles that inspired its own creation and evolution. These principles are rooted in traditions of "democracy, human rights, fundamental freedoms and the rule of law" (Tocci, 2007: 7). Today, as the result of the Lisbon Treaty, which came into force in 2009 and which has provided the EU with its first constitution, these two policies (CFSP \& ESDP) have come under the umbrella of the European Foreign and Security Policy (EFSP).

Meanwhile, in 2003, the EU published its 'Security Strategy,' which was slightly revised in 2008. In these documents, the EU identified threats to international peace and security and indicated the ways in which it sought to address these threats.

Examining the ESS, one can easily observe that the EU has taken a comprehensive approach to security where "the internal and external aspects of security are indissolubly linked" (EES, 2003: 2). According to this security approach, threats operate in the military, political, economic, societal, and environmental sectors. In addition, due to the interdependence of the security sectors, threats operating in one sector may give rise to threats in other sectors. As a result, economic failure and poverty, hunger and malnutrition, diseases and pandemics are all seen as being linked and leading to political problems and violent conflict (ESS, 2003: 2). Therefore, security is regarded as a precondition of development (ESS, 2003: 2). Conflict not only destroys infrastructure (including social infrastructure), but it also encourages criminality, deters investment and makes normal economic activity impossible. As the ESS and the 2005 Consensus on Development have acknowledged, there cannot be sustainable development without peace and security, and without development and poverty eradication there will be no sustainable peace. In other words, if security is addressed in a comprehensive way, comprehensive EU policies are needed to address security threats effectively.

Fundamentally, the EU perceives non-domestic threats in two overarching forms. Menaces stemming from states in the EU's immediate and nearby neighborhood are seen as peripheral threats, while the second class of threats is much broader, emerging from states outside of the EU's neighborhood area. The EU's security strategy is rather explicit in defining the neighborhood "as a key geographical priority of EU external action..." (Tocci 2007: 7). Tocci also draws attention to the fact that the European Neighborhood Policy (ENP) is unequivocally directed at promoting the EU's values "as a means to spread stability, security and prosperity in the southern and eastern neighbourhoods... and to strengthen the EU's contribution to the solution of regional conflicts" Tocci (2007: 7).

The changing nature of the European polity in conjunction with the limitation of individual member states' sovereignty have had important implications for the security of the European Union. For example, it has been suggested that within the EU political-territorial boundaries are growing increasingly irrelevant and that the very success of the EU has limited individual state sovereignty while has also introduced European society to a wider degree of threats (Kirchner \& Sperling, 2007: 120). According to Kirchner and Sperling (2007: 120), the 
broadening of threat stems from two conditions: first, "there has been a simple increase in the kids of threats originating within and outside the EU" and second, governments, elites, and the populace have "fundamentally changed their perception of threat as well as their collective understanding of the social and political requirements for meeting those threats." This problem is exacerbated due to the securitization of "societal vulnerabilities" and the desecuritization of the state's traditional role of protecting its territory from outside attack (Kirchner \& Sperling, 2007: 120).

Kirchner and Sperling (2007: 7) bifurcate contemporary security threats into those aimed 'above' the state and those aimed 'below' the state. The latter are generally aimed at disrupting society, while the former are more focused on targeting the governance structure or goals of member states. The ESS outlines both challenges and threats to the security and stability of the European Union.

An important challenge to security is globalism itself, which is regarded as a cause of frustration and injustice and has increased European dependency and vulnerability on "an interconnected infrastructure [of] transport, energy, and other fields" (EC, 2003: 2). In its own way, globalism exacerbates threats brought about by the openness of many EU Member States. In particular, a somewhat general sense of insecurity pervades the EU, brought about by the very fact that it is a considerably open society and open societies are often vulnerable to external disorder (Kirchner \& Sperling, 2007: 121). Failed and failing states tend to provide refuge for terrorists and transnational criminal organizations. The EU is somewhat secure considering the fact that not a single member is typically considered a failed state, but the Foreign Policy magazine (2012, Failed States Index) paints a bleak image as scores of failed or failing states are right next door to them or neighboring states. EU Member States acknowledge these threats and the fact that they require a joint action if they are to be overcome, but the EU faces a significant roadblock to this cooperative action - that being, few members are keen to relinquish their "sovereign policing or judicial prerogatives," regardless of this lack of cohesion obstructing them successfully prohibiting terrorists from acquiring chemical, biological, radiological or nuclear (CBRN) materials (Foreign Policy, 2012).

\section{European Union's Identification of Security Threats}

According to the ESS, "Europe faces new threats which are more diverse, less visible and less predictable" (ESS, 2003: 3). A set of key interrelated threats identified in the ESS document and the 2008 Report on its implementation. The first of these key threats is terrorism which imposes large costs on European societies and it seeks to undermine their openness and tolerance. The ESS views terrorism as a global phenomenon that is linked to violent religious extremism and arising out of complex causes, such as the pressures of modernization and globalization; cultural, social and political crises; and the alienation of young people living in various national societies (ESS, 2003: 3).

Since 2003 and in response to the terrorist attacks in Madrid and London, the EU has made progress in addressing security threats under the 2004 Hague Program and the new Strategy for the External Dimension of Justice and Home Affairs, adopted in 2005. These have made it easier for EU and national authorities to pursue investigations across borders and co-ordinate prosecution. The EU Counter-Terrorism Strategy, which was adopted 2005, is based on a four level approach: preventing radicalization and recruitment; protecting potential targets; pursuing terrorists; and responding to the aftermath of an attack emphasizing at the same the need for respect for human rights and international law (EC, 2008: 4). The appointment of a Counter-Terrorism Coordinator has been seen as an important step forward at the European level. However, it has been acknowledged that the EU needs to tighten coordination arrangements for handling a major terrorist incident, in particular using chemical, radiological, nuclear, and bioterrorism materials, on the basis of such existing provisions as the Crisis Coordination Arrangements and the Civil Protection Mechanism (EC, 2008: 4). The EU should further strengthen its counter-terrorism partnership with the United States in the area of data sharing and protection. Further work is also required on terrorist financing, along with an effective and comprehensive EU policy on information sharing, taking due account of protection of personal data. In addition, the EU needs to address more effectively extremist ideology and tackle discrimination. In this regard, the promotion of inter-cultural dialogue, through domestic and international fora, such as the Alliance of Civilizations, has fundamental role to play.

The second key threat is the proliferation of weapons of mass destruction. Although international treaty regimes and export control arrangements have slowed the spread of WMD and their delivery systems, advances in the biological sciences are seen as having the potential of increasing the potency of biological weapons, while attacks with chemical and radiological materials are also regarded as a serious possibility. The spread of missile technology adds a further element of instability. However, the most frightening scenario for the EU is one in 
which terrorist groups acquire weapons of mass destruction. In this event, a small group would be able to inflict damage on a scale previously possible only for national armies (ESS, 2003: 4).

Security risks associated with the proliferation of WMD has increased since the ESS was adopted in 2003. While Libya has dismantled its WMD program, the policies and actions of Iran and North Korea have challenged the international community. A likely revival of civil nuclear power in coming decades also poses challenges to the non-proliferation system, if not accompanied by the right safeguards. To address threats stemming from the proliferation of WMD, the EU has been very active in multilateral fora and at the forefront of international efforts to address Iran's nuclear program. The ESS emphasizes prevention, by working through the UN and multilateral agreements as well as with third countries and regional organizations to enhance their capabilities to prevent proliferation. Nevertheless, more work is needed to address issues, such as countering financing of proliferation; taking measures on bio-safety and bio-security; and containing proliferation of delivery systems (notably ballistic missiles). The EU has demonstrated its willingness to support negotiations on a multilateral treaty banning production of fissile material for nuclear weapons and work on strengthening the non-proliferation regime by pursuing disarmament and ensuring the responsible development of peaceful uses of nuclear energy.

In addition to the security threats associated with WMD, the 2008 Report focused on threats stemming from the proliferation of Small Arms and Light Weapons (SALW), Cluster Munitions and Landmines (EC, 2008: 8-9). In 2005, the European Council adopted the EU Strategy to combat illicit accumulation and trafficking of SALW and their ammunition. In the context of its implementation, the EU has supported the UN Program of Action in this field and has pledged to continue developing activities to combat threats posed by illicit SALW. In addition, the EU has given strong support to the concept of an international Arms Trade Treaty and has decided to support the process leading towards its adoption. The EU is also a major donor to anti-mine action. It has actively supported and promoted the Ottawa Convention on Anti-Personnel Landmines worldwide. The Oslo Convention on Cluster Munitions, agreed at Dublin in May 2008, represents an important step forward in responding to the humanitarian problems caused by this type of munitions, which constitute a major concern for all EU Member States. The adoption of a protocol on this type of munitions in the UN framework involving all major military powers constitutes a primary EU policy objective in this field.

Another key threat to the EU is associated with regional conflicts. Violent or frozen conflicts and problems such as those in the Middle East, Central Asia, Africa, and the Korean Peninsula are all viewed as having the potential of impacting European interests and security directly and indirectly. For example, they may destroy human lives and social and physical infrastructures as well as threaten minorities, fundamental freedoms and human rights. Conflict can also lead to extremism, terrorism, state failure and provide opportunities for organized crime (ESS, 2003: 4). Regional insecurity that might be resulted from domestic conflicts and state failure can also fuel the demand for WMD.

Bad governance - reflected in corruption, abuse of power, weak or collapsed institutions and lack of accountability - and civil conflict lead to state failure that is regarded as a key threat to the EU's security (ESS, 2003: 4). Therefore, spreading good governance, supporting social and political reform, dealing with corruption and abuse of power, establishing the rule of law and protecting human rights are viewed by the EU as the best means for increasing European security. Because state failure can lead to organized crime and/or terrorism, the EU uses a variety of tools, including political and economic conditionality, to ensure the establishment of well-governed democratic states.

Organized crime is regarded as one of the main threats to EU's internal security (ESS, 2003: 4). However, this internal threat has an important external dimension associated with terrorism, cross-border trafficking in drugs, women, illegal migrants and weapons. Such criminal activities are often associated with weak or failing states. Revenues from drugs can fuel the weakening of state structures, while revenues from trade in gemstones, timber and small arms can fuel conflict in other parts of the world. All these activities are viewed as undermining both the rule of law and social order itself. Since 2003, organized crime has continued to impact European states and societies with trafficking in drugs, human beings, and weapons, alongside international fraud and money laundering. The 2008 Report acknowledges that progress in fighting organized crime has been slow and incomplete and highlights the necessity to improve the way in which the EU brings together the internal and external dimensions of organized crime (EC, 2008: 4). According to the 2008 Report, better co-ordination, transparency and flexibility are needed across different agencies, at national and European level. Consequently, existing partnerships with neighboring states and within the UN should be deepened, in addressing movement of people, police and judicial cooperation. Implementation of existing UN instruments on crime is essential. The 
EU also needs to strengthen state capacity in world regions, such as South Asia, Africa, and the EU's southern neighborhood as well as support multilateral efforts, principally in the UN.

The ESS identified piracy as a new dimension of organized crime. The 2008 Report highlighted it further. According to the 2008 Report, piracy is a result of state failure (EC, 2008: 8). Because the world economy relies on sea routes for $90 \%$ of trade, piracy has become a pressing security issue. Piracy in the Indian Ocean and the Gulf of Aden has made this issue even more pressing in recent months because it affected delivery of humanitarian aid to Somalia. The EU has responded with ATALANTA (the EU's first maritime ESDP mission), to deter piracy off the Somali coast, alongside countries affected and other international actors, including NATO.

Since modern economies are heavily dependent on critical infrastructure including transport, communication, power supplies, and the internet, the 2008 Report emphasized the importance of a security threat that was not identified in the ESS, namely cyber security (EC, 2008: 5). The EU Strategy for a Secure Information Society, adopted in 2006, addresses internet-based crime. However, attacks against private or government IT systems in EU Member States have given this a new dimension, as a potential new economic, political and military weapon. Therefore, more work is required in this area, to explore a comprehensive EU approach, raise awareness and enhance international cooperation.

Although discussion about the importance of energy featured in the ESS, energy security gained prominence in the 2008 Report. This was mainly due to the increase of concerns about energy dependence. Declining of production inside Europe has meant that by 2030 up to $75 \%$ of the EU's oil and gas would have to be imported from a limited number of countries, many of which face threats to stability. Therefore, the 2008 Report has called for an EU energy policy which combines external and internal dimensions. According to the 2008 Report, there is a need for a more unified energy market within the EU, with greater inter-connection, and particular attention to the most isolated countries and crisis mechanisms to deal with temporary disruption to supply. At the same time, greater diversification of fuels, sources of supply, and transit routes is regarded essential, as are good governance, respect for rule of law and investment in source countries (EC, 2008: 5). This implies that the EU should pursue a policy of engagement with Central Asia, the Caucasus and Africa, as well as through the Eastern Partnership and the Union for the Mediterranean. Moreover, because energy is a major factor in EU-Russia relations, EU policy should address transit routes, including through Turkey and Ukraine. Finally, in collaboration with major international actors, such as China, India, Japan and the US, the EU should promote renewable energy, low-carbon technologies and energy efficiency, alongside transparent and well-regulated global markets.

In 2003, the ESS already identified the security implications of climate change. Since 2003, however, this has taken on a new urgency. In March 2008, the High Representative and the European Commission presented a report to the European Council which described climate change is a 'threat multiplier'. For example, natural disasters, environmental degradation and competition for resources have the potential of exacerbating conflict, especially in situations of poverty and population growth, with humanitarian, health, political and security consequences, including greater migration. Climate change can also lead to disputes over trade routes, maritime zones and resources previously inaccessible.

\section{European Union's Strategic Objectives}

Taking into account the threats mentioned above, the ESS identifies three strategic objectives: addressing the threats facing the EU; building security in the EU's neighborhood; and promoting an international order based on effective multilateralism. Since the EU's response to security threats was addressed in the previous section, this section will focus on the latter two strategic objectives.

\subsection{Building Security in the Neighborhood}

Given the interdependence of the security threats, neighboring states engaged in violent conflict, weak states where organized crime flourishes, dysfunctional societies or exploding population growth on the EU's borders all can be seen as posing problems for EU security. Thus it has been in the EU's interest that countries on its borders are well-governed (EES, 2003: 7). The importance of this is best illustrated in the Balkans. Through concerted efforts with the US, Russia, NATO and other international partners, the stability of the region is no longer threatened by the outbreak of major conflict.

The integration of acceding states has brought the EU closer to troubled areas. Therefore, the main EU task has been the promotion of a ring of well governed countries to the East of the EU and on the borders of the Mediterranean with whom the EU enjoys cooperative relations. Consequently, the EU has sought to extend the benefits of economic and political cooperation to its eastern neighbors while tackling political problems there. 
For example, the EU has taken a stronger and more active interest in the problems of the Southern Caucasus, while the resolution of the Arab-Israeli conflict has been a strategic priority for Europe for without this, there would be little chance of dealing with other problems in the Middle East. The EU must remain engaged and ready to commit resources to the problem until it is solved. The implementation of the two-state solution, which the EU has supported and it is now widely accepted, will require a concerted effort by the EU, Russia, the United States, the UN and the countries of the region, but most important, it will require the engagement of the Israelis and the Palestinians themselves.

The EU's interests in the Mediterranean area, which continues to undergo serious problems of economic stagnation, social unrest and unresolved conflicts, require a continued engagement with Mediterranean partners, through more effective economic, security and cultural cooperation in the framework of the Barcelona Process. A broader engagement with the Arab World should also be considered.

\subsection{An International Order Based on Effective Multilateralism}

According to the ESS, "in a world of global threats, global markets and global media" EU's security and prosperity "increasingly depend on an effective multilateral system" (ESS 2003: 9). Therefore, the development of well-functioning international institutions and a rule-based international order are identified as fundamental EU objectives. In this context, the EU is committed to upholding and developing international law and work within the framework of the UN Charter where the Security Council has the primary responsibility for the maintenance of international peace and security. Moreover, it is considered in the EU's interest that global and regional international organizations, regimes and treaties are effective in confronting threats to international peace and security. Because regional organizations strengthen global governance, for the EU the strength and effectiveness of the OSCE and the Council of Europe has a particular significance. One of the core elements of the ESS is the transatlantic relationship with NATO being an important expression of this relationship (Bishop \& Lembke, 2008; Forsberg \& Herd, 2006). Other regional organizations such as ASEAN, MERCOSUR and the African Union are also seen as making important contributions to international peace and stability (Soderbaum \& Stalgen, 2010; De Lombaerde \& Schulz, 2009).

The ESS notes that "the quality of international society depends on the quality of the governments that are its foundation" (ESS, 2003: 10). As a result, the best protection for the EU's security is a world of well-governed democratic states. Trade and development policies are seen as powerful tools for promoting democratic reforms. Contributing to better governance through assistance programs, conditionality and targeted trade measures remains an important feature in EU's policy.

Having identified the security threats facing the EU and its strategic objectives, the discussion will now turn to the question of capabilities available to the EU to achieve these objectives. This discussion is associated with the question of the EU's identity as a 'civilian', 'military', and 'normative power'.

\section{EU as a 'Civilian' Power}

The idea that civilian forms of power have become important instruments to deal effectively with threats to international peace and stability has been central to the post-Cold War security considerations. The debate regarding whether military power is still the key to international security has produced a general consensus that although it still plays an important role in ensuring international order, it is often ill-suited to solve the complex political and security problems the international community faces today (Everts \& Schmitt, 2004). It has been claimed that the more states rely on hard power and coercion, the less successful they are in deploying soft power and persuasion. It has also been argued that international stability largely depends on the existence of socio-politically strong states (Buzan, 1991; Holsti, 1996) and, therefore, the key to international order is helping the transformation of weak states into strong ones. However, creating strong states and rebuilding war-torn societies is much more expensive and time-consuming than war fighting. More importantly, it requires a long political commitment by the members of the international community and the use of civilian forms of power.

The idea that EU could become a different kind of power that does not rely primarily on military but on civilian means was first explicitly formulated in the early 1970's by Francois Duchene (1973). 'Civilian power' has been defined as involving three key features: the centrality of economic power to achieve national goals; the primacy of diplomatic cooperation to solve international problems; and the willingness to use legally binding supranational institutions to achieve international progress (Twitchett, 1976: 1-2). Specifically, Hans Maull (1990: 92-3) defines a civilian power as a state "whose conception of its foreign policy role and behavior is bound to particular aims, values, principles, as well as forms of influence and instruments of power in the name of a civilization of international relations." Given the EU's emphasis on multilateralism and its willingness to use 
trade and development assistance to achieve international peace and security, one could safely argue that the EU constitutes a civilian power.

On 9 May 2000, to celebrate the 50th anniversary of the Schuman Declaration, the EU distributed publicity material declaring ' 50 Years of Solidarity, Prosperity and Peace'. According to this material, Europe in the year 2000 saw itself as representing a 'civilian power', which was "long on economic power and relatively short on armed force". The status of the EU as a global civilian power was pronounced by Romano Prodi (2000: 3) who stated that "We must aim to become a global civil power at the service of sustainable global development. After all, only by ensuring sustainable global development can Europe guarantee its own strategic security."

However, Hedley Bull criticized the notion of EEC as a 'civilian power' for its ineffectiveness and lack of self-sufficiency in military power and suggested that the EEC should become more self-sufficient in defense and security (Bull, 1982: 152). The inability of the EU to deal with the Yugoslav crisis made several scholars and practitioners to argue about the need of the EU to develop and deploy its military power.

\section{EU as a 'Military' Power}

Since the defeat of the European Defense Community in 1954, the question of the EEC assuming a military dimension had remained taboo until the Treaty on European Union (TEU) was signed in 1991. As Richard Whitman (1998: 135-6) has suggested, the TEU had signaled the intent of the Member States of the Union to move beyond a 'civilian power Europe' and to develop a defense dimension to the international identity of the Union', shattering that taboo. According to Ian Manners (2002: 237), the move from the single structure of the EC to the three-pillar structure of the EU was part of a "fundamental shift from civilian to military power, assuming that the development of a common foreign and security policy was eventually to include defense policy." However, for the next several years the expectations of foreign policy and military power were not matched by the hoped for achievements of the European Union. This disappointment, which Christopher Hill (1993) felt was a 'capabilities-expectation gap', was grounded on unreal expectations which Helen Sjursen (1998) termed an 'eternal fantasy'.

The trend towards 'military power Europe' is currently to be found in the European Security and Defense Policy (ESDP) agreed upon at the June 1999 Cologne European Council which committed the EU to having a 60,000-person rapid reaction force (RRF) ready by the end of 2003 (Stivachtis, $2004 \& 2005$ ). While the formal preparation for the Petersberg Tasks of the RRF might be seen by some as evidence of movement towards a 'military power Europe' (Manners, 2002: 237), others have argued that these tasks are still within the remit of a 'civilian power' as the questions of defense and nuclear capability still remain the concern of NATO (Jorgensen 1997; Smith 2000). However, the development of EFSP has made it clear that questions of defense are now fall within 'military power Europe'. This militarization of the EU is not without criticism. For example, it has been argued that it weakens the EU's 'distinct profile' of having a civilian international identity (Zielonka, 1998: 229). Nevertheless, Richard Whitman (2006: 103) argues that regardless of the development of ESDP, the notion of a 'civilian power EU' still holds considerable weight in the international community.

The Cold War, which structured many of the assumptions associated with military power and nits effectiveness, ended with the internal collapse of regimes across Central and Eastern Europe whose ideology was perceived as unsustainable by its leadership and citizens. These intra-state changes came about by the collapse of the norms associated with communism. Thus, according to Manners (2002: 238), a better understanding of the EU's role in world politics might be gained by reflecting on what those revolutions tell us about the power of ideas and norms rather than the power of empirical force - in other words the role of normative power.

\section{EU as a 'Normative Power'}

Richard Rosecrance (1998: 22) has argued that "Europe's attainment is normative rather than empirical" and that "it is perhaps a paradox to note that the continent which once ruled the world through the physical impositions of imperialism is now coming to set world standards in normative terms." The idea of normative power in the international sphere is not new. For example, E.H Carr made the distinction between economic power, military power and power over opinion (Carr, 1962: 108). Duchene was also interested in the normative power of the EC as an 'idee force', starting with the beliefs of the 'founding fathers' and extending through its appeal to widely differing political temperaments (Duchene, 1973: 7). Elements of this normative power can also be found in the critical perspective of Johann Galtung who stated that "ideological power is the power of ideas" (Galtung, 1973: 33). Galtung argues that ideological power is "powerful because the power sender's ideas penetrate and shape the will of the power-recipient' through the media of culture" (Galtung, 1973: 33). He differentiated between channels of power (ideological power, remunerative power and punitive power) and sources of power (resource 
power and structural power) and claimed that this distinction is "fundamental, because it is on the latter that the European Community is particularly strong, even more so than the United States" (Galtung ,1973: 36).

Adopting Rosecrance's argument and by thinking beyond traditional conceptions of the EU's international role, Manners sought to illustrate that the EU should be best conceived as a 'normative power Europe'. (Manners 2002: 238). His effort begins by briefly surveying the conceptual history of 'civilian power' and 'military power Europe' since the early 1980s in order to locate these traditional conceptions of the EU's international role. He then introduces the idea of 'normative power Europe,' he discusses the EU's normative difference and normative basis, and explains how EU norms are diffused. He concludes that the concept of 'normative power' represents a valuable addition to one's own understanding of the EU's civilian and military power in world politics. Thus, for Manners, the notion of 'normative power' when applied to the EU is not a contradiction in terms, as the ability to define what passes for 'normal' in world politics is extremely rich.

Manners' empirical evidence that the EU is a normative power relies largely on the policies it pursues. Specifically, investigating the EU's normative basis, Manners argues that unlike what happened with historical empires and contemporary global powers, the EU's normative difference comes from its historical context, hybrid polity and political-legal constitution (Manners, 2002: 240).

The broad normative basis of the EU has been developed over the past fifty years through a series of declarations, treaties, policies, criteria and conditions (Christiansen, 1997; Weiler, 1999; Laffan, 2001). According to Manners (2002), it is possible to identify five 'core' norms within this vast body of Union laws and policies, which comprise the acquis communautaire and acquis politique. The first of these is the centrality of 'peace', found in key symbolic declarations such as that by Robert Schuman in 1950, as well as the preambles to the European Coal and Steel Treaty in 1951 and the Treaty of the European Community (TEC) of 1957. The second is the idea of 'liberty' found in the preambles of the TEC and the TEU of 1991, and in Article 6 of the TEU, which sets out four foundational principles of the Union. The third, fourth and fifth norms are democracy, the rule of law, and respect for human rights and fundamental freedoms, all of which are expressed in the preamble and founding principles of the TEU, the development co-operation policy of the Community (TEC art. 177), the common foreign and security provisions of the Union (TEC art. 11), and the membership criteria adopted at the Copenhagen European Council in 1993.

Manners suggests four additional 'minor' norms within the constitution and practices of the EU (Manners 2002: 243-44). The first minor norm is the notion of 'social solidarity' found throughout the acquis communautaire et politique of the EU, but in particular the preambles of the TEC and TEU, the objectives of Article 2 (TEU) and Article 2 (TEC), and the central focus of both the EC's social policy and the Economic and Social Committee. The second minor norm is 'anti-discrimination' found in Article 13 and Title Xl of the TEC, as well as the 'protection of minorities' found in the Copenhagen criteria. The third minor norm is that of 'sustainable development' enshrined in Article 2 (TEU), Article 2 (TEC) and the all-encompassing Article 6 (TEC). The fourth minor norm is the most recent and has yet to find any formal expression in treaty form, but is implicit in the Copenhagen criteria. This norm is the principle of 'good governance' as found in Romano Prodi's inaugural speech to the European Parliament (Prodi 2000), as well as Commission papers on 'EU election assistance and observation' and the 'White Paper on European Governance' (cited in Manners, 2002: 242).

The reinforcement and expansion of the norms identified by Manners allows the EU to present and legitimize itself as being more than the sum of its parts. In the post-Cold War era, it is no longer enough for the EU to present itself as merely a form of economic government for the management of global economics, as the increasing resistance by its citizens to economic liberalization suggests. This desire for greater legitimacy through the fundamental norms that the EU represents has most recently found an expression in the Charter of Fundamental Rights of the EU adopted at the Nice European Council in December 2000. The Charter restates and re-emphasizes the core and minor norms, except 'good governance', with the aim of ensuring that basic political and social rights become more widely known to the EU citizenship, although 'the charter does not establish any new power or task' (Art. 49) and will not form part of the EC/EU treaty base in the immediate future.

The Lisbon Treaty has largely occurred as an elite-driven, treaty-based, legal order. For this reason its constitutional norms represent crucial constitutive factors determining its international identity. The principles of democracy, rule of law, social justice and respect for human rights were first made explicit in the 1973 Copenhagen Declaration on European Identity, although the centrality of many of these norms was only constitutionalized in the TEU. As it has been suggested that "a strong commitment to human rights is one of the principal characteristics of the European Union" (Alston \& Weiler, 1999: 6). This argument has received support 
from many scholars. For example, Von Bogdandy (2000: 1307) observes that "a most prominent piece of evidence is the European Council's decision at its Cologne Summit was that a human rights charter should be drafted for the European Union" because "protection of fundamental rights is a founding principle of the Union and an indispensable prerequisite for her legitimacy." Likewise, Lenaerts and de Smijter (2001: 273) argue that 'some thirty years before this decision, the Court of Justice had already confirmed that "fundamental human rights [are] enshrined in the general principles of Community law and protected by the Court."

This combination of historical context, hybrid polity and legal constitution has, in the post-cold war period, accelerated a commitment to placing universal norms and principles at the centre of its relations with its Member States (Merlingen et al., 2001) and the world (Clapham, 1999; Smith, 2001). Manners argues that the EU has gone further towards making its external relations informed by, and conditional on, a catalogue of norms which come closer to those of the European Convention on Human Rights and Fundamental Freedoms (ECHR) and the Universal Declaration of Human rights (UDHR) than most other actors in world politics (Manners, 2002: 241). As he rightly points out, the EU is founded on and has as its foreign and development policy objectives the consolidation of democracy, rule of law, and respect for human rights and fundamental freedoms (TEU, art. 6, art. 11, and TEC, art. 177). Furthermore it is committed to pursuing these norms in accordance with the ECHR (TEU, art. 6) and 'the principles of the United Nations Charter' (TEU, art. 11, preamble to TEC).

According to Thomas Diez, the discursive construction of the EU as a normative power is one that most EU politicians - in Council, Commission and Parliament as well as on the member state level - engage in unless they are committed Eurosceptics. As Diez puts it, "there may well be disagreement about the development of the EU's military capacities between Council and Commission, and between different member states and different directorate-generals, yet the representation of Europe as a force for peace and well-being is nearly consensual" (Diez, 2005: 619).

\section{Civilian, Military and Normative Power and the Implementation of the European Security Strategy}

The ESS and the 2008 Report identified ways in which the EU should employ its civilian, military and normative power in order to strengthen its security and promote a more peaceful international order.

Specifically, the ESS noted that the EU should be more active in pursuing its strategic objectives (ESS, 2003: 11). This applies to the full spectrum of instruments for crisis management and conflict prevention at the EU's disposal, including political, diplomatic, military and civilian, trade and development activities. Active policies are also needed to counter the new dynamic threats together with a strategic culture that fosters early, rapid, and robust intervention (Gariup, 2009). According to the ESS and the 2008 Report, as a Union of twenty-seven members, spending more than 160 billion Euros on defense, the EU should be able to sustain several operations simultaneously by developing operations involving both military and civilian capabilities. The EU should also reinforce its cooperation with the UN to assist countries emerging from conflicts, and to enhancing its support for the UN in short-term crisis management situations (Gourlay, 2009; Tocci, 2007). The EU also needs to be able to act before countries in its neighborhood deteriorate, when signs of proliferation are detected, and before humanitarian emergencies arise. Preventive engagement can avoid more serious problems in the future. With the establishment of EFSP, the EU has made considerable progress towards a coherent foreign policy and effective crisis management.

A more capable EU requires the transformation of its militaries into more flexible and mobile forces. To enable these forces to address the new threats, more resources for defense and more effective use of resources are necessary (ESS, 2003: 4). Systematic use of pooled and shared assets would reduce duplications, overheads and, in the medium-term, increase capabilities. Because in almost every major intervention, military efficiency has been followed by civilian chaos, the EU needs greater capacity to bring all necessary civilian resources to bear in crisis and post crisis situations (EC, 2008: 9). Stronger diplomatic capability implies the establishment of a system that combines the resources of Member States with those of EU institutions. Moreover, dealing with problems that are more distant requires better understanding and communication. Common threat assessments are the best basis for common actions. This requires improved sharing of intelligence among member states and with partners. As the Union increases capabilities in the different areas, it should also think in terms of a wider spectrum of missions. This might include joint disarmament operations, support for third countries in combating terrorism and security sector reform. The last of these would be part of broader institution building. Finally, the EU-NATO permanent arrangements, in particular Berlin Plus, enhance the operational capability of the EU and provide the framework for the strategic partnership between the two organizations in crisis management.

EU policy should also be more coherent (ESS, 2003: 5). The point of the EFSP is that the EU is stronger when its Member States act together. The challenge is to bring together the different instruments and capabilities, such 
as European assistance programs and the European Development Fund as well as military and civilian capabilities from Member States and other instruments. All of these can have an impact on EU's security and on that of third countries. Diplomatic efforts, development, trade and environmental policies should follow the same direction. In a crisis there is no substitute for unity of command. Better coordination between external action and Justice and Home Affairs policies is crucial in the fight both against terrorism and organized crime (Stetter, 2007). But greater coherence is needed not only among EU instruments but also embracing the external activities of the individual Member States. As experience in the Balkans and West Africa has shown, coherent policies are also needed regionally, especially in dealing with conflict. Problems are rarely solved on a single country basis or without regional support.

Since there are no international problems a country can deal on its own, the EU needs to work with partners. EU needs to pursue its objectives both through multilateral cooperation in international organizations and through partnerships with key actors. The transatlantic relationship is irreplaceable (Bishop \& Lembke 2008: Forsberg \& Herd 2006; Howorth \& Keeler 2003; Sloan 2003). Despite their differences, acting together the EU and the United States can be a formidable force for peace and stability in the world (McGuire \& Smith 2008). Therefore, EU's aim should be an effective and balanced partnership with the United States. This is an additional reason for the EU to build up further its capabilities and increase its coherence. Finally, the EU should look to develop strategic partnerships with major international players, such as Russia, Japan, China, Canada and India as well as with all those states which share its goals and values and are prepared to act in their support. This is particularly important in order to establish a legitimate and stable global order. Yet, history, geography and cultural ties give EU links with its neighbors in the Middle East and its partners in Africa, Latin America, and Asia (Soderbaum \& Stalgren, 2010; De Lombaerde \& Schultz, 2009; Telo, 2007). These relationships are an important asset to build on in an effort to create a 'better world'.

\section{Conclusion}

The purpose of this essay was to examine the EU's conceptualization of peace and security and discuss how EU seeks to contribute to international order and stability. The paper commenced with a discussion of the EU's understanding of peace and security and then proceeded with the EU's identification of threats to its security and international peace. Then, it focused on the EU's security strategy to identify how the EU seeks to address challenges to international order and stability. Finally, the paper employed the concepts of 'civilian', 'military' and 'normative power Europe' to demonstrate how the EU attempts to create international security and stability both at the regional and international levels. In so doing, the paper argued that the EU employs both 'civilian' and 'military' means in the application of its 'normative' power.

Overall, in addressing threats that undermine international peace and security, the EU has been reacting overwhelmingly with civilian or normative power, only making use of military power when situations have become critically dire. While all three types of power: civilian, normative and military are alive and well, there appears to be a clear progression in the order in which they are put into practice, with military power being brought to bear last in nearly all cases one may observe. Duchene's forty year old statements on the 'twentieth-century citizen's notion of civilized politics' may well be holding true.

\section{References}

Alston, P., \& Weiler, J. (1999). An 'Ever Closer Union' in Need of a Human Rights Policy: The European Union and Human Rights. In P. Alston (Ed.), The EU and Human Rights. Oxford: Oxford University Press.

Andersson, J., et al. (2011). The European Security strategy: Reinvigorate, Revise or Reinvent? UI Occasional Papers, Swedish Institute of International Affairs.

Bishop, S., \& Johan, L. (Eds.). (2008). EU Enlargement and the Transatlantic Alliance: A Security Relationship in Flux. Boulder, CO: Lynne Rienner.

Bull, H. (1982). Civilian Power Europe: A Contradiction in Terms?. Journal of Common Market Studies, 21(2), 149-164. http://dx.doi.org/10.1111/j.1468-5965.1982.tb00866.x

Buzan, B. (1991). People, States and Fear (2nd ed.). London: Harvester Wheatsheaf.

Carr, E. H. (1962). The Twenty Years' Crisis 1919-1939 (2nd ed.). London: Macmillan.

Christiansen, T. (1997). Legitimacy Dilemmas in Supranational Governance. In N. Nentwich, \& A. Weale (Eds.), Political Theory and the European Union. London: Routledge.

Clapham, A. (1999). Where is the EU's Human Rights Common Foreign Policy, and How is it Manifested in Multilateral Fora? In P. Alston (Ed.), The EU and Human Rights. Oxford: Oxford University Press. 
De Lombaerde, P., \& Schutz, M. (Eds.) (2009). The EU and World Regionalism. Aldershot: Ashgate.

Duchene, F. (1972). Europe's Role in World Peace. In R. Mayne (Ed.), Europe Tomorrow. London: Fontana.

Duchene, F. (1973). The European Community and the Uncertainties of Interdependence. In M. Kohnstamm, \& W. Hager (Eds.), A Nation Writ Large? Foreign Policy Problems before the European Community. Basingstoke: Macmillan.

Elgstrom, O., \& Smith, M. (2006). The European Union's Roles in International Politics. London: Routledge.

European Commission. (2008). Report on the Implementation of the European Security Strategy: Providing $\begin{array}{llllll}\text { Security In } & a & \text { Changing } & \text { World. } & \text { Retrieved } & \text { from }\end{array}$ http://www.consilium.europa.eu/ueDocs/cms_Data/docs/pressdata/EN/reports/104630.pdf

European Commission. (2012a). EU Awarded the Nobel Peace Prize. Retrieved from $\mathrm{http} / / /$ ec.europa.eu/languages/news/20121012-eu-nobel-peace-prize_en.htm

European Commission. (2012b). Joint statement of José Manuel Barroso, President of the European Commission, and Herman Van Rompuy, President of the European Council on the award of the 2012 Nobel Peace Prize to the EU. Retrieved http://europa.eu/rapid/press-release_MEMO-12-779_en.htm\#PR_metaPressRelease_bottom

European Commission. The Schuman Declaration: 9 May 1950. Retrieved from http://europa.eu/about-eu/basic-information/symbols/europe-day/schuman-declaration/index_en.htm

European Security Strategy. (2003). A Secure Europe in a Better World. Retrieved from http://www.consilium.europa.eu/uedocs/cmsUpload/78367.pdf

Everts, S., \& Schmitt, G. (2004). Is Military Power Still the Key to International Security?. For and Against: Debating Euro-Atlantic Security Options. Brussels: NATO.

Foreign Policy. (2012). Failed States 2012 Edition. Retrieved from http://www.foreignpolicy.com/failed_states_index_2012_interactive

Forsberg, T., \& Herd, G. P. (2006). Divided West: European Security and the Transatlantic Relationship. London: Chatham House.

Galtung, J. (1973). The European Community: A Superpower in the Making. London: Allen \& Unwin.

Gariop, M. (2009). European Security Culture: Language, Theory, Policy. Aldershot: Ashgate.

Gourlay, C. (2009). EU-UN Cooperation in Peacebuilding: Partners in Practice? Geneva: United Nations.

Hill, C. (1993). The Capability-Expectations Gap, or Conceptualizing Europe's International Role. Journal of Common Market Studies, 31(3), 305-328. http://dx.doi.org/10.1111/j.1468-5965.1993.tb00466.x

Holsti, K. (1996). The State, War, and the State of War. Cambridge: Cambridge University Press. http://dx.doi.org/10.1017/CBO9780511628306

Howorth, J., \& Keeler, J. T. S. (Eds.). (2003). Defending Europe: The EU, NATO and the Quest for European Autonomy. New York: Palgrave. http://dx.doi.org/10.1057/9781403981363

Jorgensen, K. E. (1997). Western Europe and the Petersberg Tasks. In K. E. Jorgenson (Ed.), European Approaches to Crisis Management (pp. 131-152). The Hague: Kluwer Law International.

Kirchner, E., \& Sperling, J. (2007). EU Security Governance. Manchester, Manchester University Press.

Laffan, B. (2001). The European Union Polity: A Union of Regulative, Normative and Cognitive Pillars. Journal of European Public Policy, 8(5), 709-727. http://dx.doi.org/10.1080/13501760110083473

Lenaerts, K., \& de Smitjer, E. (2001). A 'Bill of Rights' for the European Union. Common Market Law Review, 38(2), 273-300. http://dx.doi.org/10.1023/A:1010670801584

Leonard, M., \& Gowan, R. (2004). Global Europe: Implementing the European Security Strategy. The British Council Brussels.

Lundin, L. E. (2012). From European Security Strategy to a European Global Strategy. UI Occasional Papers, Swedish Institute of International Affairs.

Manners, I. (2002). Normative Power Europe: A Contradiction in Terms? Journal of Common Market Studies, 40(2), 235-258. http://dx.doi.org/10.1111/1468-5965.00353 
Manners, I., \& Whitman, R. (1998). Towards Identifying the International Identity of the European Union. Journal of European Integration, 21(2), 231-249. http://dx.doi.org/10.1080/07036339808429068

Maull, H. (1990). German and Japan: The New Civilian Powers. Foreign Affairs, 69(5), 91-106. http://dx.doi.org/10.2307/20044603

McGuire, S., \& Michael, S. (2008). The European Union and the United States. Basingstoke: Palgrave.

Merlingen, M., \& Ostrauskaitè, R. (2006). European Union Peacebuilding and Policing: Governance and the European Security and Defense Policy. London: Routledge.

Merlingen, M., Mudde, C., \& Sedelmeier, U. (2001). The Right and the Righteous? European Norms, Domestic Politics and Sanctions Against Austria. Journal of Common Market Studies, 39(1), 59-77. http://dx.doi.org/10.1111/1468-5965.00276

Orbi, J. (Ed.). (2009). Europe's Global Role: External Policies of the European Union. Aldershot: Ashgate.

Prodi, R. (2000). 2000-2005: Shaping the New Europe. Speech to the European Parliament, Strasburg, 15 February.

Rosecrance, R. (1998). The European Union: A New Type of International Actor. In J. Zieloka (Ed.), Paradoxes of European Foreign Policy (pp. 15-23). The Hague: Kluwer Law International.

Sjursen, H. (1998). Missed Opportunity or Eternal Fantasy?: The Idea of a European Security and Defense Policy. In J. Peterson, \& H. Sjursen (Eds.), A Common Foreign Policy for Europe? Competing Visions of the CFSP. London: Routledge.

Sloan, S. R. (2003). NATO, the European Union and the Atlantic Community. Lanham: Rowman \& Littlefield.

Smith, K. (2000). The End of Civilian Power EU: A Welcome Demise or Cause for Concern?. International Spectator, 23(2), 11-28. http://dx.doi.org/10.1080/03932720008458123

Smith, K. (2001). The European Union, Human Rights and Relations with Third Countries: Foreign Policy with an Ethical Dimension. In K. Smith, \& M. Light (Eds.), Ethics and Foreign Policy. Cambridge: Cambridge University Press. http://dx.doi.org/10.1017/CBO9780511491696.011

Soderbaum, F., \& Stalgren, P. (Eds.). (2010). The European Union and the Global South. Aldershot: Ashgate.

Stetter, S. (2007). EU Foreign and Interior Policies. London: Routledge.

Stivachtis, Y. A. (2004). "Common Foreign and Security Policy (CFSP) and European Security and Defense Policy (ESDP) After Iraq". In Y. A. Stivachtis (Ed.), Current Issues in European Integration. Athens: ATINER.

Stivachtis, Y. A. (2005). The European Defense and Security Policy: Evolution and Changes. In Y. A. Stivachtis (Ed.), Global Governance and International Security. Athens: ATINER.

Stivachtis, Y. A. (Ed.). (2007). The State of European Integration. Aldershot: Ashgate.

Stivachtis, Y. A. (Ed.). (2010). The New Europe: Politics, Economic and Foreign Relations. Athens: ATINER.

Telo, M. (Ed.). (2007). European Union and New Regionalism: Regional Actors and Global Governance in a Post-Hegemonic Era (2nd ed.) Aldershot: Ashgate.

Therborn, G. (1977). Europe in the Twenty-First Century. In P. Gowan, \& P. Anderson (Eds.), The Question of Europe. London: Verso.

Tocci, N. (2007). The EU and Conflict Resolution: Promoting Peace in the Backyard. London: Routledge.

Twitchett, K. (Ed.). (1976). Europe and the World; The External Relations of the European Market. New York: St. Martin's Press.

Von Bogdandy, A. (2000). The European Union as a Human Rights Organization? Human Rights and the Core of the European Union. Common Market Law Review, 37, 1307-138.

Weiler, J. (1999). The Constitution of Europe. Cambridge: Cambridge University Press.

Whitman, R. (1998). From Civilian to Superpower? The International Identity of the European Union. Basingstoke: Macmillan. http://dx.doi.org/10.1057/9780230375956

Zielonka, J. (1998). Explaining Euro-paralysis: Why Europe is Unable to Act in International Politics: Basingstoke: Macmillan. http://dx.doi.org/10.1057/9780230372849 


\section{Copyrights}

Copyright for this article is retained by the author(s), with first publication rights granted to the journal.

This is an open-access article distributed under the terms and conditions of the Creative Commons Attribution license (http://creativecommons.org/licenses/by/3.0/). 